\title{
Active uptake of kleptoplastids by Dinophysis caudata from its ciliate prey Myrionecta rubra
}

\author{
Susanna Minnhagen ${ }^{1}$, Miran Kim ${ }^{2}$, Paulo S. Salomon ${ }^{1}$, Wonho Yihh $^{3}$, Edna Granéli ${ }^{1}$, \\ Myung Gil Park ${ }^{2, *}$
}

\author{
${ }^{1}$ University of Kalmar, 39182 Kalmar, Sweden \\ ${ }^{2}$ Laboratory of HAB Ecophysiology (LOHABE), Department of Oceanography, Chonnam National University, \\ Gwangju 500-757, Republic of Korea \\ ${ }^{3}$ Department of Oceanography, Kunsan National University, Gunsan 573-701, Republic of Korea
}

\begin{abstract}
We verified an active uptake of kleptoplastids in the toxic and bloom-forming dinoflagellates of the genus Dinophysis from its preferred prey, the ciliate Myrionecta rubra, using a quantitative real-time PCR technique. During a 65 d starvation/feeding experiment with Dinophysis caudata, changes in plastid 16S rRNA, plastid autofluorescence and plastid/nuclear DNA ratio through the cell cycle were followed with quantitative real-time PCR and flow cytometry. During starvation, the cultures initially showed a rapid growth and a 3.5-fold increase of number of cells $\mathrm{ml}^{-1}$, while at the same time, plastid DNA cell ${ }^{-1}$ showed a 3.5-fold decrease, and a 3.6-fold decrease in phycoerythrin fluorescence cell ${ }^{-1}$. The decrease in plastid DNA cell ${ }^{-1} \mathrm{~d}^{-1}$ closely followed culture growth rate (Pearson correlation, $r=0.91$ ), indicating that existing plastids were diluted within the growing population and that no new plastids were synthesised by the cells. When starved cells were re-fed by the ciliate M. rubra on Days 43 to 51 of the experiment, plastid DNA cell ${ }^{-1}$ increased 7 -fold up to 14000 16S DNA copies per cell, thereby directly revealing the kleptoplastic behaviour. The implication is that not only availability of the prey $M$. rubra itself, but also the supply of suitable kleptoplastids might be an important controlling factor for Dinophysis spp. bloom formation and decline.
\end{abstract}

KEY WORDS: Dinophysis $\cdot$ Myrionecta rubra $\cdot$ Kleptoplastid $\cdot$ Real-time PCR

\section{INTRODUCTION}

The photosynthetic dinoflagellates of the genus Dinophysis are common members of marine planktonic communites in both coastal and oceanic waters, where they often form seasonal blooms. Many Dinophysis species have been reported to produce diarrheic shellfish poison and they are included in the list of potential harmful algal bloom (HAB) species (www. marinespecies.org/hab/index.php). What triggers and sustains Dinophysis blooms in marine waters has been debated, but recent important findings on the biology and ecology of the genus have cast new light onto the subject. For several Dinophysis species, culture experiments have shown that they are obligate mixotrophs, feeding on the ciliate Myrionecta rubra (Park et al. 2006, 2008, Kim et al. 2008, Nagai et al. 2008, Nishitani et al. 2008a). The relative importance of photosynthe- sis and phagotrophy for Dinophysis has been studied in the field and in cultures and results lean towards the conclusion that they use phagotrophy as their main feeding strategy, but also have good photosynthetic capabilities, especially after recent feeding (Carvalho et al. 2008, Kim et al. 2008, Riisgaard \& Hansen 2009). It has long been suspected that they practice a life strategy called kleptoplasty, but this has been difficult to prove and much discussed as a result of contradictory findings (Melkonian 1996, Takishita et al. 2002, Janson 2004, Minnhagen \& Janson 2006, Minnhagen et al. 2008, Nagai et al. 2008, Park et al. 2008, GarciaCuetos et al. 2010). Kleptoplasty is a life strategy whereby a host is specialized in feeding on a narrow range of plastid-containing prey and, seemingly as an extra bonus, has the ability to store these plastids and use them for photosynthesis in their own cells (Blackbourn \& Taylor 1973, Trench 1975, Lopez 1979, 
Schnepf \& Elbrachter 1992). Alternatively, Dinophysis could have permanent secondary plastids, which is a far more common strategy among microalgae (Keeling 2010).

Plastids are semi-autonomous, i.e. they are partly responsible for their own metabolic processes. Parts of their old genome remain from the time when they were cyanobacteria, encoding the building blocks for the photosynthetic apparatus. However, they are not completely autonomous because some essential genes are missing from the plastid bacterial genome, for example the ones encoding their own division (Strepp et al. 1998). With the right conditions provided, a plastid taken up by a host can continue to be photosynthetically active, but there are significant differences between kleptoplastidic species regarding the time the plastids can maintain their metabolic activity within their host (Skovgaard 1998, Nowack \& Melkonian 2010). For example, kleptoplastidic dinoflagellates of the genera Gymnodinium and Amphidinium loose their plastids within $2 \mathrm{wk}$ in culture if kept without plastid-containing prey, and are sometimes found completely without plastids (Wilcox \& Wedemayer 1984, Larsen 1988, Fields \& Rhodes 1991, Horiguchi \& Pienaar 1992, Skovgaard 1998). In contrast, Dinophysis spp. retain plastids, even after long periods of starvation.

To resolve whether the Dinophysis plastid should be regarded as a kleptoplastid or a permanent secondary plastid, one first needs to clarify what distinguishes these 2 types. A plastid that is truly permanent in the evolutionary context should not only be stable and maintained with resources from the host, but the host must also have the genes that encode for plastid replication and thus be able to produce new plastids by itself. In the case of a permanent plastid, no active uptake of plastids from the environment is expected. In contrast, a kleptoplastidic strategy involves an active continuous uptake of plastids from prey, and thus does not require their long-term maintenance or the replication of new plastids. The difference is not clear-cut, however, because there are examples of kleptoplastidic species where some, but not all, genes needed for plastid maintenance have been transferred to the host genome (Rumpho et al. 2008), or where a prey nucleus is kept within the cell to enable plastid replication (Johnson et al. 2007).

Most studies to date suggest that Dinophysis species are kleptoplastidic. Phylogenetic studies comparing Dinophysis spp. plastid gene sequences (i.e. the 16S rRNA block, tufA, rbcL, $p s b \mathrm{~A}$ and $p s a \mathrm{~A}$ ) to those from free-living cryptophytes and from the ciliate Myrionecta rubra support the kleptoplastid theory as they have shown that the plastids are genetically identical to each other (Takishita et al. 2002, Janson \& Granéli
2003, Hackett et al. 2004, Janson 2004, Takahashi et al. 2005, Minnhagen \& Janson 2006, Nagai et al. 2008, Nishitani et al. 2008b, Park et al. 2008, Garcia-Cuetos et al. 2010). However, as some authors have pointed out, plastid genes are conservative so it might not be entirely safe to draw the conclusion that plastids are transferred directly from M. rubra to Dinophysis spp. based solely on genetic evidence (Park et al. 2008, Garcia-Cuetos et al. 2010). In addition to the phylogenetic studies, sequestration of kleptoplastids by $D$. fortii when feeding on $M$. rubra has been directly observed by microscopy (Nagai et al. 2008), and a cell cycle study has shown that $D$. norvegica do not replicate their plastids when dividing themselves, which is consistent with a kleptoplastidic strategy (Minnhagen et al. 2008). However, 2 transmission electron microscope (TEM) studies which address the morphological characteristics of the plastid support instead the idea of a permanent plastid (Schnepf \& Elbrachter 1988, Garcia-Cuetos et al. 2010). Garcia-Cuetos et al. (2010) argue that, although genetically identical, the plastids within $D$. acuminata are morphologically different from the plastids within M. rubra.

Hitherto, Dinophysis spp. have only been maintained for long periods of time in cultures when fed Myrionecta rubra (Park et al. 2006, Nagai et al. 2008, Nishitani et al. 2008a,b, Garcia-Cuetos et al. 2010). $M$. rubra in turn has plastids originating from free-living cryptophytes (Gustafson et al. 2000, Yih et al. 2004, Johnson \& Stoecker 2005, Hansen \& Fenchel 2006). It is likely that $M$. rubra can take up and store plastids from some similar cryptophyte species belonging to the Teleaulax/Geminigera/Plagioselmis complex (Park et al. 2007, Nishitani et al. 2008b), which is not completely resolved. Some heterogenic cryptophyte plastid DNA, presumably transferred to the dinoflagellate via the ciliate, has also been found inside single cells of Dinophysis spp. from field samples (Hackett et al. 2004, Minnhagen \& Janson 2006) and in culture studies (Park et al. 2010). These findings also support the kleptoplastid hypothesis; however, it cannot be completely excluded from the field studies that some of this plastid DNA from prey species could also be derived from undigested contents within the food vacuoles (Garcia-Cuetos et al. 2010).

In the present study, we used quantitative real-time PCR and fluorescence measurements to search for evidence of kleptoplasty, or alternatively, replicating permanent plastids, during a starvation/feeding experiment with Dinophysis caudata. In addition, cell cycle analyses and cell sorting by flow cytometry to estimate nuclear and plastid DNA content in cells from different stages of the cell cycle were carried out to further address the question about possible plastid replication in Dinophysis. 


\section{MATERIALS AND METHODS}

Cultures and experimental setup. Culture conditions of organisms used in this study were as described in Park et al. (2006, 2008). Stock cultures of Dinophysis caudata strain DC-LOHABE01 were grown using the marine ciliate Myrionecta rubra strain MR-MAL01 as prey in $30 \mathrm{psu} \mathrm{f} / 2-\mathrm{Si}$ medium ( $+5 \% \mathrm{v} / \mathrm{v}$ soil extract) at $20^{\circ} \mathrm{C}$ and a $14 \mathrm{~h}$ light:10 h dark cycle, with cool-white fluorescent lamps providing $50 \mu \mathrm{mol}$ photons $\mathrm{m}^{-2} \mathrm{~s}^{-1}$. Stock cultures of $M$. rubra were grown using the cryptophyte strain CR-MAL01 as prey (Yih et al. 2004, Park et al. 2007). The cryptophyte culture was grown under the same conditions as described above for D. caudata.

Before the starvation/feeding experiment, stock cultures of Dinophysis caudata in exponential growth were fed Myrionecta rubra daily for 1 wk to ensure that the dinoflagellate culture was well fed. The wellfed $D$. caudata were then washed free of prey using gentle gravity filtration through $20 \mu \mathrm{m}$ Nitex mesh, split into 3 aliquots and then diluted with fresh medium to prepare triplicate $400 \mathrm{ml}$ flasks at cell densities of approximately 1000 cells ml $\mathrm{m}^{-1}$. The flasks were incubated under the same conditions as mentioned above. During the starvation/feeding experiment, the cultures were first starved for $43 \mathrm{~d}$. Of the initial 3 replicate cultures, 2 were lost during this period, so only 1 culture remained throughout the experiment. At Day 43 (43 d from the start of the experiment), the cells were fed with dense (ca. $10^{4}$ cells $\mathrm{ml}^{-1}$ ) M. rubra cultures at intervals of 2 to $3 \mathrm{~d}$ during an $8 \mathrm{~d}$ period. After that they were starved for a second period of $22 \mathrm{~d}$ until Day 73 when the experiment ended.

Sampling and microscopy. Samples were collected on 16 occasions during the experiment at Days $0,1,3$, $6,9,12,17,22,43,51,54,57,60,63,68$ and 73. From Day 0 to Day 17, 3 replicate samples were collected from each of the 3 replicate cultures, at Day 22 from 2 replicate cultures and from Day 43 onward from the 1 remaining culture. During the feeding period (Days 44 to 50), no samples were collected.

Estimates for cell abundance were obtained from acid Lugol-fixed (final concentration $2 \%$ ) $3 \mathrm{ml}$ samples by enumerating cells present in microscope transects (100× magnification) of duplicate Sedgewick-Rafter chambers. For each chamber, all of the chamber area was examined. From cell abundance data, culture growth rate $\left(K^{\prime}\right)$ was calculated using:

$$
K^{\prime}=\ln \left(N_{2} / N_{1}\right) /\left(t_{2}-t_{1}\right)
$$

where $\mathrm{N}_{2}$ and $\mathrm{N}_{1}$ are number of cells $\mathrm{ml}^{-1}$ at times $t_{2}$ and $t_{1}$, respectively. Frequency of single, just divided and paired cells was determined by scoring all cells per chamber as single, just divided or paired (Fig. 1). Light micrographs of the live cells were taken at 400 or
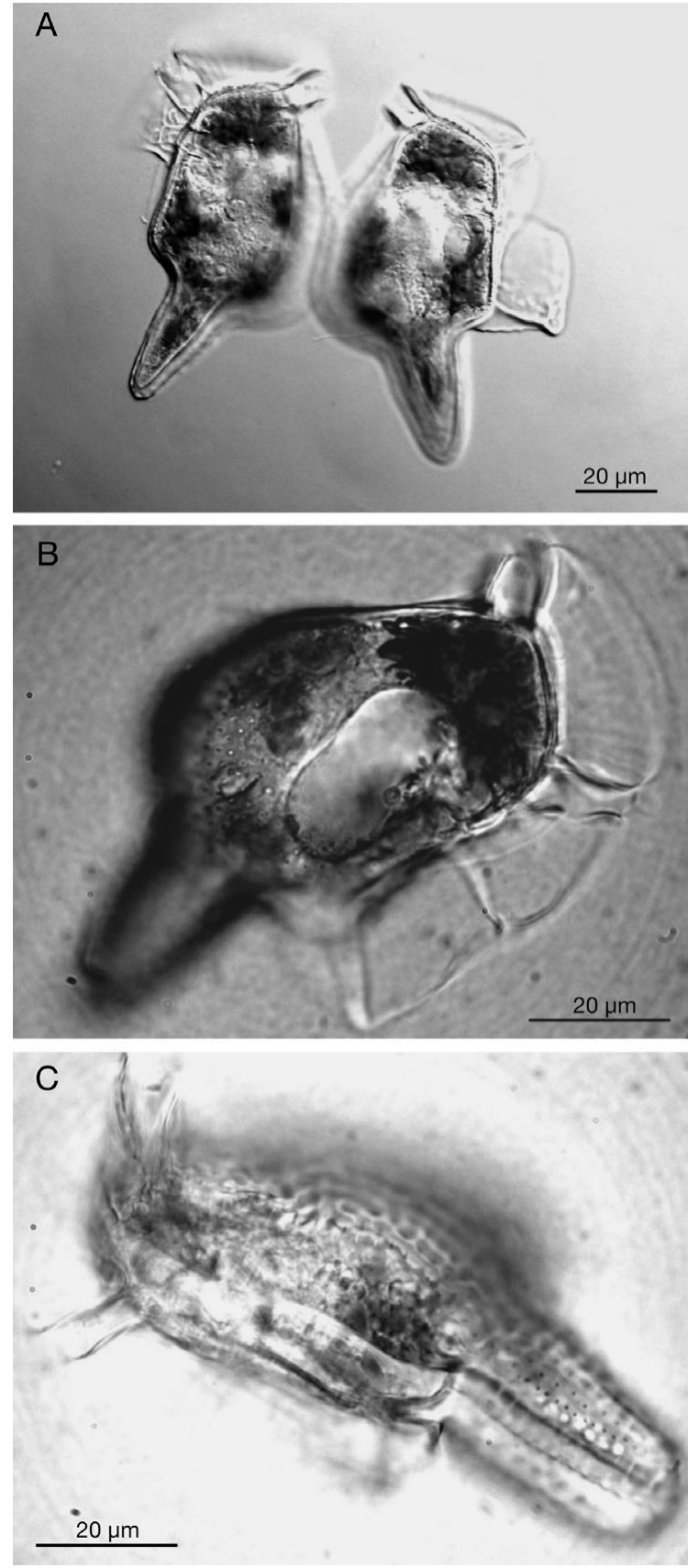

Fig. 1. Dinophysis caudata. (A) Paired, (B) single and (C) just divided cells

1000× magnification using a digital camera (Canon PowerShot G5) coupled to the Olympus BX51 microscope (Olympus) equipped with differential interference.

Preservation of cells for follow-up DNA and phycoerythrin fluorescence analyses was performed as follows: $4 \mathrm{ml}$ of culture was transferred into a sterile tube and incubated with $10 \%$ (w/v) paraformaldehyde, $\mathrm{pH}$ 6.8 buffered with $100 \mathrm{mM}$ phosphate-buffered saline 
(PBS), for $1 \mathrm{~h}$ at room temperature. The fixed cells were then washed twice in $20 \mathrm{mM}$ PBS by centrifugation for removal of the supernatant, resuspended in $70 \%(\mathrm{v} / \mathrm{v})$ ethanol and stored at $-20^{\circ} \mathrm{C}$ until analyses. In addition, from Days 1, 3 and 6, 3 aliquots containing ca. 10000 extra cells from each replicate culture were fixed for cell cycle analyses. Cells from Day 1 were also used to establish initial conditions with which the other samples were compared.

Fluorescence measurements. Before analyses, samples from Days 1 to 22 were filtered through a $100 \mu \mathrm{m}$ mesh to remove large particles. Cells were then washed gently with Tris-EDTA (TE) buffer ( $\mathrm{pH}$ 8.0) to remove the fixatives and resuspended in TE buffer spiked with approximately 2000 fluorescent $10 \mu \mathrm{m}$ calibration beads (Duke Scientific). Phycoerythrin fluorescence was measured in individual cells from samples from Days 1 to 22 using a FACS Vantage SE flow cytometer (Becton Dickinson). A $488 \mathrm{~nm}$ laser line was used for excitation and the fluorescence signal was collected through a 585/42 $\mathrm{nm}$ bandpass filter. Average fluorescence from $3000 \pm 1000$ cells per sample was quantified in relation to the fluorescence of the calibration beads.

Cell cycle analyses and cell sorting. Samples from Days 1 to 6 were filtered through a $100 \mu \mathrm{m}$ mesh, washed twice with $20 \mathrm{mM}$ PBS pH 7.9, treated with $0.1 \mathrm{mg} \mathrm{ml}^{-1}$ RNase A (Roche) for $1 \mathrm{~h}$ at $37^{\circ} \mathrm{C}$, and then stained with $8 \mu \mathrm{M}$ SYTOX Green (Molecular Probes) according to Gisselson et al. (2002). The suspension of stained cells in TE buffer was spiked with calibration beads as before and analysed in the flow cytometer in which a $488 \mathrm{~nm}$ laser line was used for excitation and the SYTOX Green fluorescence signal was collected as pulse area (FL-1-A) through a 530/30 nm bandpass filter. SYTOX Green stained Dinophysis caudata cells were assigned to either the G1 or G2M group based on their fluorescence (see Fig. 6), and the different cell types were sorted by flow cytometry and collected into different tubes for follow-up DNA analyses.

Quantitative real-time PCR. Three real-time PCR assays were set up for Dinophysis caudata, targeting (1) the plastid 16S rRNA gene using primers Cry-1 + Cry-2 specific for cryptophyte plastid DNA (Minnhagen \& Janson 2006); (2) the plastid psbA gene, using primers TamF (5'-GTC AGC TAA CTA CGG T-3') specific for Teleaulax amphioxeia plastid DNA + psbAcryR (5'-GGT TAG CAC GGT TAA G -3') specific for cryptophyte plastid DNA, corresponding to positions 693-708 and 961-976 of the Guillardia theta plastid genome (Douglas \& Penny 1999); and (3) the nuclear ITS1-5.8S region, using primers ITS1-dinoF + 5.8S-dinoR specific for Dinophysis spp. (Penna et al. 2007). All primers were purchased from Eurofins MWG Operon. The unstained cells were washed in TE buffer to remove preservatives, and from each culture and sample dates from Day 0 to Day 72, 3 replicate samples containing ca. 1000 unstained cells were transferred into $1.5 \mathrm{ml}$ maximum recovery tubes (Axygen). From the SYTOX Green stained cells that had been sorted by flow cytometry and separated into tubes containing only G1 or G2M cells (described earlier), 3 replicate samples with ca. 500 cells per tube were made from each culture, sampling date and G1 or G2M phase. DNA from both unstained and stained cells was extracted according to the method described by Minnhagen et al. (2008).

A $3 \mu \mathrm{l}$ aliquot of DNA extract was used as template to a final volume of $20 \mu \mathrm{l}$ reaction mix, and PCR duplicates were made from each replicate sample. The content of 16S rDNA was measured in all samples, and in samples from Days 0 to 22, the plastid psbA gene was also measured. We used IQTM SYBR Green Supermix (Bio-Rad) for fluorescence detection, and the primers were added to a final concentration of $0.6 \mu \mathrm{M}$ for the 16S rDNA and ITS1-5.8S assays and $0.8 \mu \mathrm{M}$ for the psbA assay. All real-time PCR assays were run separately, using a MJ Mini Personal Thermal Cycler (BioRad) with accompanying software. The thermal cycle for all assays was set up as follows: $3 \mathrm{~min}$ at $95^{\circ} \mathrm{C}$, followed by 40 cycles of $15 \mathrm{~s}$ at $95^{\circ} \mathrm{C}, 15 \mathrm{~s}$ at melting temperature $\left(T_{\mathrm{m}}\right.$, specific for each set of primers used in the PCR) and $10 \mathrm{~s}$ at $72^{\circ} \mathrm{C}$, and then for each cycle a plate was read. After 40 cycles, a melt curve from 55 to $95^{\circ} \mathrm{C}$ with a plate read every $0.5^{\circ} \mathrm{C}$ was run to check the quality of the amplified DNA. $T_{\mathrm{m}}$ was $52.2^{\circ} \mathrm{C}$ for the 16S rDNA assay, $51.4^{\circ} \mathrm{C}$ for the psbA assay and $49^{\circ} \mathrm{C}$ for the ITS1-5.8S assay.

Calculation of plastid DNA per cell. Normalization of the real-time PCR data and relative quantification of the amount of plastid DNA per cell were done according to the Pfaffl method (Pfaffl 2001). The plastid 16S rRNA and $p s b A$ genes were our target sequences, the nuclear ITS1-5.8S gene was our reference sequence and samples from Day 1 were used as controls. The results were given as relative amount of the target gene in our samples compared with the controls.

Two sets of standard curves were constructed (Fig. 2), one cell-based to determine the PCR efficiencies $(E)$ for use in the equations described in Pfaffl (2001) and one plasmid-based to enable an absolute quantification of number of plastid $16 \mathrm{~S}$ rRNA and $p s b \mathrm{~A}$ gene copies cell ${ }^{-1}$. The plasmid standard was constructed with 10-fold serial dilutions of the manufactured plasmid pCR2.1 with one synthesised insert of each target gene (Eurofins MWG Operon), ranging from $10^{7}$ to $10^{3}$ copies per reaction. The cell standard was constructed with Day 1 cells that were treated in the same way as the samples, in 2-fold serial dilutions ranging from 2.5 to 80 cells per reaction. Each standard curve was run 3 times, and then $E$ was calculated from 


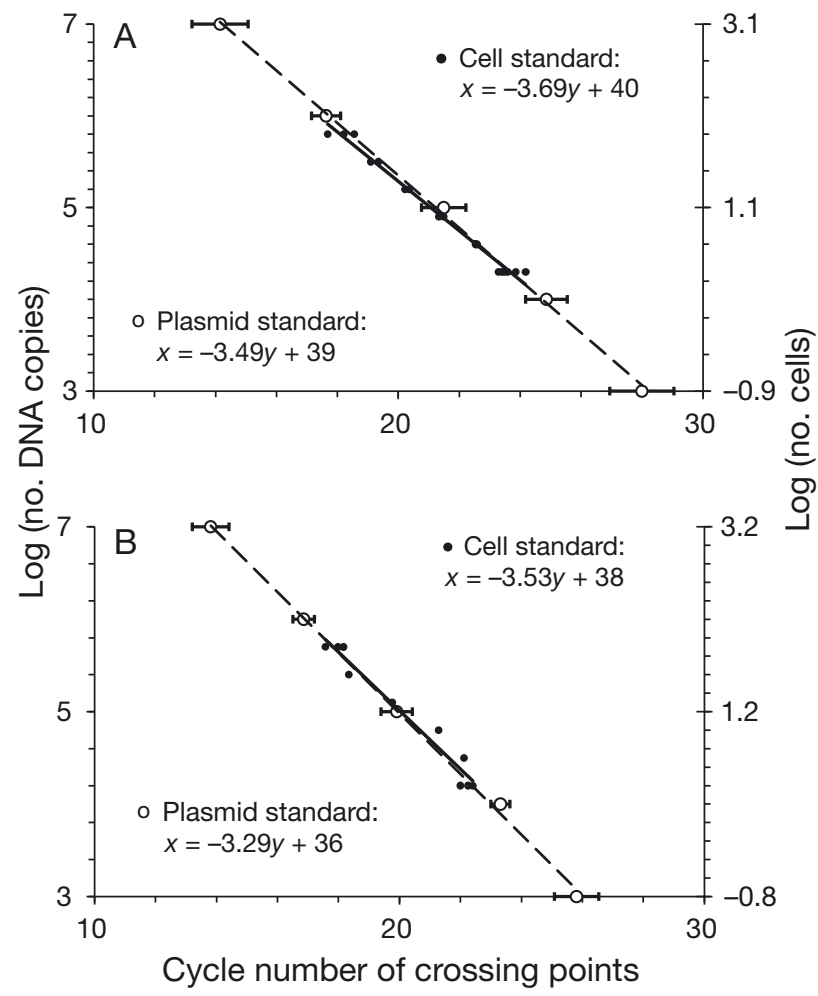

Fig. 2. Average standard curves for (A) the 16S rDNA assay and (B) the psbA gene assay. Bars show SD ( $\mathrm{n}=3)$. Cycle number of crossing points is the number of PCR cycles needed for the SYBR Green fluorescence from each sample to rise appreciably above the background fluorescence (Pfaffl 2001). Thresholds for background fluorescence were set manually to $0.016 \Delta \mathrm{R}_{\mathrm{n}}$ for the psbA and ITS1-5.8S assays and to $0.02 \Delta R_{n}$ for the $16 \mathrm{~S}$ rDNA assay

the average slopes of the standard curves (Fig. 2) using the formula $E=10^{(-1 / \text { slope })}$. $E$ was 1.87 for the $16 \mathrm{~S}$ rDNA assay, 1.87 for the ITS1-5.8S assay and 1.93 for the psbA assay, as determined from the cell standard.

The absolute numbers of 16S rRNA and psbA gene copies cell ${ }^{-1}$ at Day 1, $P($ Day 1$)$, were estimated graphically by overlapping the 2 standard curves (plastid and cell-based) for each assay and using the formula:

$$
P(\text { Day } 1)=10^{y} / 10^{z}
$$

where $y$ is the log of DNA copies (referring to the plasmid standard) and $z$ the log of cell numbers (referring to the cell standard) for a given cycle number of crossing points in the quantitative real-time PCR assay, and can be directly taken from the left respectively right $y$ axis for any particular cycle number of crossing points in the linear fits shown in the Fig. 2. Given $P($ Day 1), the absolute number of target gene copies cell ${ }^{-1}$ in each sample from Days 0 to 65 was calculated by multiplying with the relative amount of target gene per sample, explained earlier.
The change with time in plastid DNA per cell, or 'plastid loss rate', $P^{\prime}$ (to compare with culture growth rate, $K^{\prime}$ ), was calculated as follows:

$$
P^{\prime}=\ln \left(P_{2} / P_{1}\right) /\left(t_{2}-t_{1}\right)
$$

where $P_{2}$ and $P_{1}$ are number of plastid 16S rRNA gene copies cell ${ }^{-1}$ at times $t_{2}$ and $t_{1}$, respectively.

Diagnostic real-time PCR. In addition to the quantitative real-time PCR assays described above, 2 diagnostic real-time PCR assays with primers targeting DNA from the prey species Myrionecta rubra were run on the Dynophysis caudata samples from Days 0, 1, 3, 6, 51 and 54. These assays were carried out to investigate whether, despite physical absence from prey in the cultures, prey DNA could be amplified from remaining prey DNA inside the food vacuoles of $D$. caudata. If present, such prey DNA remains could have theoretically affected our measurements of plastid 16S rRNA. The primer pairs used for diagnostic PCR were: (1) M. rubra specific $18 \mathrm{~S}$ rDNA primer MRF (Johnson et al. 2006) plus general eukaryotic primer 1629R (Janson et al. 2000); and (2) Teleaulax amphioxeia specific 18S rDNA primer Tx (Minnhagen \& Janson 2006) plus general eukaryotic primer EUK2 (Janson et al. 2000). The T. amphioxeia nuclear DNA was targeted based on the findings that cryptophyte nuclei can be found inside of M. rubra (Johnson et al. 2007). DNA extracted from a field sample of $M$. rubra was used as positive controls for both assays, and thermal cycles were the same as described above with $T_{\mathrm{m}}=$ $49^{\circ} \mathrm{C}$. The resulting PCR products were evaluated by melting curve analyses from 55 to $95^{\circ} \mathrm{C}$ with a plate read every $0.5^{\circ} \mathrm{C}$ to check for different fragments sizes. To summarise and illustrate the results, PCR products from Days 0, 1 and 51 plus positive controls, and for comparison products from the Dinophysis ITS1-5.8S and 16S rDNA assays, were loaded on an agarose gel for physical band separation.

\section{RESULTS AND DISCUSSION}

\section{Culture growth, plastid DNA cell ${ }^{-1}$ and fluorescence during starvation/feeding conditions}

When the initially well-fed cultures were deprived from the ciliate Myrionecta rubra, each Dynophysis caudata cell contained 8300 copies of the 16S rRNA gene and 6000 copies of the psbA gene, as determined from the standard curves in Fig. 2. Cell numbers in the cultures compared with plastid 16S rDNA copies cell ${ }^{-1}$ throughout the experiment are shown in Fig. 3A. The cultures continued to grow during the first $22 \mathrm{~d}$ of starvation, showing a 3.5-fold increase in cell numbers during this time. At the same time, the number of copies of 

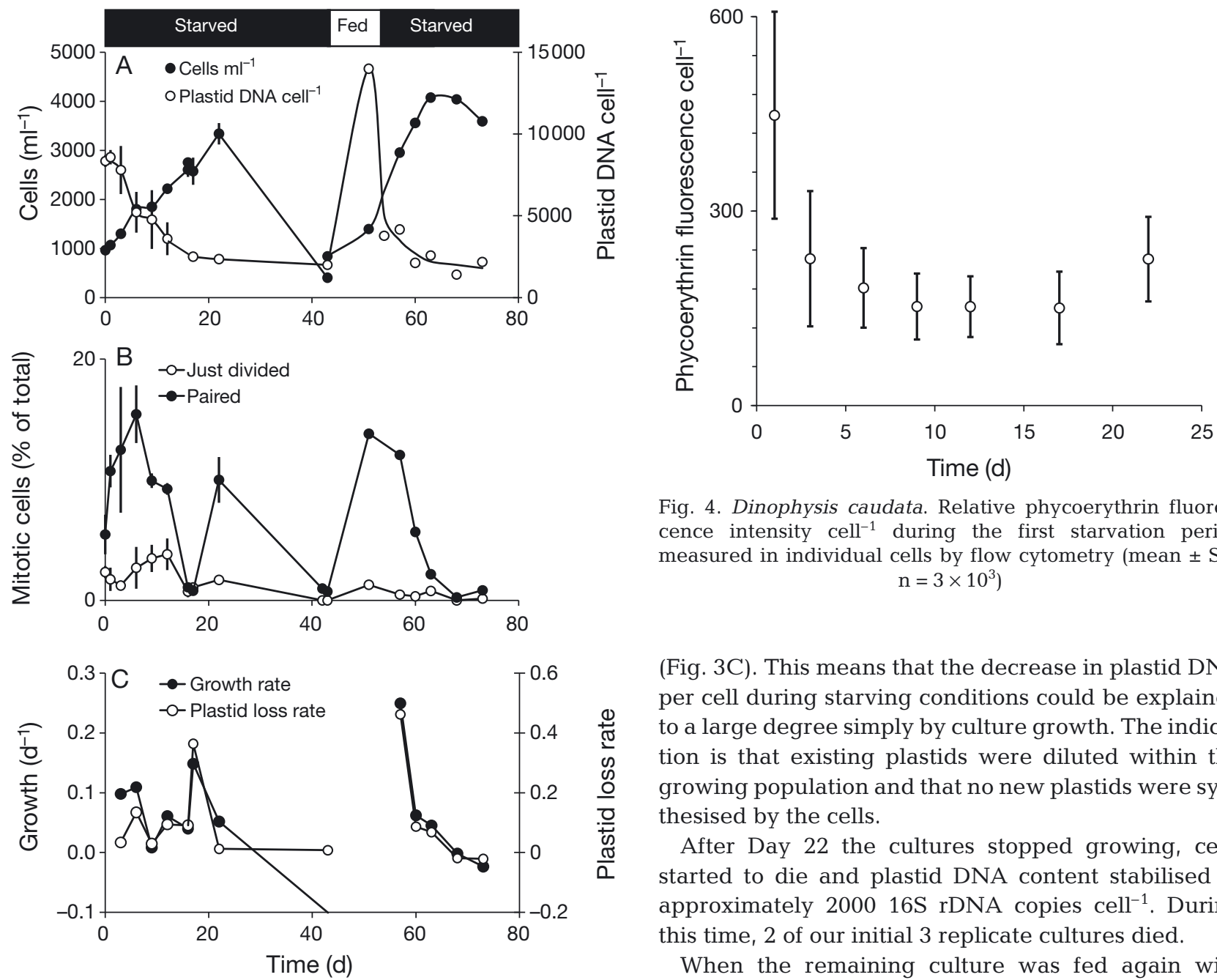

(Fig. 3C). This means that the decrease in plastid DNA per cell during starving conditions could be explained to a large degree simply by culture growth. The indication is that existing plastids were diluted within the growing population and that no new plastids were synthesised by the cells.

After Day 22 the cultures stopped growing, cells started to die and plastid DNA content stabilised at approximately $200016 \mathrm{~S}$ rDNA copies cell ${ }^{-1}$. During this time, 2 of our initial 3 replicate cultures died.

When the remaining culture was fed again with Myrionecta rubra for 8 d between Days 43 and 51, plastid DNA cell ${ }^{-1}$ showed a 7 -fold increase reaching up to $1400016 \mathrm{~S} \mathrm{rDNA}$ copies cell ${ }^{-1}$, the highest plastid DNA level measured during the experiment. In principle, some of the $16 \mathrm{~S}$ rDNA amplified from cells collected at Day 51 could have been from M. rubra in food vacuoles, but since no nuclear 18S DNA from M. rubra could be amplified from this, or from any of the other samples tested with prey-specific primers (Fig. 5), the implication is that prey DNA in the food vacuoles was rapidly digested and that the $16 \mathrm{~S}$ rDNA measured at this point came from Dynophysis caudata plastids. The culture now started to grow again and reached the highest cell number during the experiment. Both the increase in cell numbers and the rate of plastid DNA loss cell ${ }^{-1}$ were faster during the second starvation period compared with the first starvation period (Fig. 3A,C). After $12 \mathrm{~d}$ into the second starvation period, the growth stopped, and at this point plastid DNA once again had decreased to a level of approximately $200016 \mathrm{~S}$ rDNA copies cell ${ }^{-1}$. This might be a threshold level, below which the photosynthesis in a 


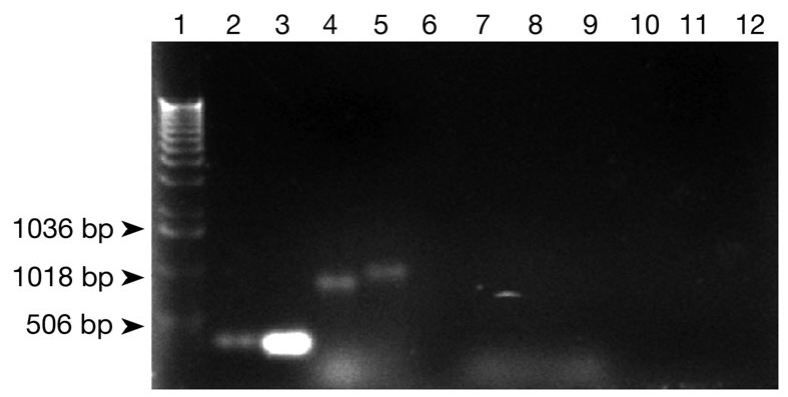

Fig. 5. Non-quantitative summary of our real-time PCR results. As all PCR products were evaluated by melting curve analyses directly after PCR, only a selection of samples were run on this agarose gel to illustrate the results. Lane 1: molecular weight marker 10 (Roche). Lane 2: Day 0, primers targeting Dinophysis ITS1-5.8S. Lane 3: Day 0, primers targeting Dinophysis 16S rDNA. Lane 4: Myrionecta rubra environmental sample, primers targeting $M$. rubra $18 \mathrm{~S}$ rDNA. Lane 5: $M$. rubra environmental sample, primers targeting Teleaulax amphioxeia 18S rDNA. Lane 6: negative control from the Dinophysis ITS1-5.8S assay. Lane 7: Day 0, primers targeting $M$. rubra $18 \mathrm{~S}$ rDNA. Lane 8: Day 1, primers targeting $M$. rubra 18S rDNA. Lane 9: Day 51, primers targeting $M$. rubra 18S rDNA. Lane 10: Day 0, primers targeting T. amphioxeia 18S rDNA. Lane 11: Day 1, primers targeting T. amphioxeia 18S rDNA. Lane 12: Day 51, primers targeting T. amphioxeia 18S rDNA

cell can no longer provide the necessary impetus for further division. After this point, cell numbers started to decline again and the experiment was terminated.

It was evident that Dinophysis caudata cells were capable of quickly increasing their levels of plastid DNA when fed. Could this dramatic increase in plastid DNA have been a result of their own plastid DNA replication, given that they now received the nutrients and growth factors needed from food? As the cells increased in number, the simultaneous increase in plastid DNA cell ${ }^{-1}$ was equivalent to more than a doubling per cell and per day during the $8 \mathrm{~d}$ that they were fed. If they had the ability to carry out such plastid DNA replication, why would this efficient replication stop immediately when the cells were deprived of food yet continued to rapidly grow in cell number? We know that most cells at the beginning of both starvation periods had cellular resources available for 2 replications of their full nuclear genome, i.e. divisions, as deduced from the increase in total cell number during these periods. For a mixotrophic species with permanent plastids, it would be more believable if they kept up their photosynthetic capability on the same or even higher level when no other carbon source was available, provided they had the resources for replication (Adolf et al. 2006).

What would be expected of a kleptoplastidic species? When deprived of their plastid-carrying prey, kleptoplastidic cells cannot acquire new plastids either from their environment or through their own plastid replication, because they lack some parts of the plastid replication mechanism. As a result, the plastids will be diluted for every cell division until cell division stops, and only increase again when the cells are fed. This is the pattern seen in the present experiment, and the implication is that Dinophysis caudata actively must obtain kleptoplastids from Myrionecta rubra. An alternate explanation for our results could be that $D$. caudata have some sort of semi-permanent plastids, which are not completely exchanged with fresh plastids, but regularly need to be boosted by genes or other components from $M$. rubra to become fully functional and divide.

\section{Cell cycle analysis}

To further address the question about possible plastid DNA replication within Dinophysis spp. we used the cell cycle approach described in an earlier field study by Minnhagen et al. (2008), this time with the sampling performed in cultures. Two examples of histograms from the cell cycle analyses and how the cells were assigned to different groups determined from the cells' relative fluorescence are shown in Fig. 6. These groups were physically separated in the flow cytometer, and when checked under the microscope, the G1 group contained single cells (Fig. 1B), while the G2M group was dominated by paired cells (Fig. 1A).

The frequency of mitotic and paired cells (Fig. 3B) indicates that cell division in the cultures was partly synchronized. The maximum frequency of paired cells was found at Day 3 in Culture B and at Day 6 in Cultures $\mathrm{A}$ and $\mathrm{C}$, meaning that around this time a big cohort of cells had passed through their first division during starving conditions. When analysed for their plastid DNA content, both G1 and G2M cells showed a steady decrease in plastid DNA per cell that was proportional to the population growth (Fig. 7). At Day 6, cells from the G2M group had significantly lower levels of plastid DNA than did the G1 cells. This result shows that when grown in culture under starved conditions, the cells that went through division first, i.e. the paired cells, were the ones leading the overall trend of decreasing plastid DNA cell ${ }^{-1}$. As we know from microscopy that the frequency of paired cells peaked at Day 6, an apparent explanation for the pattern seen is that it reflects a separation of existing plastids specifically linked to cell division. We cannot completely rule out the possibility of some minor plastid replication with this approach, but it is clear from this experiment that for the bulk of cells that had passed 


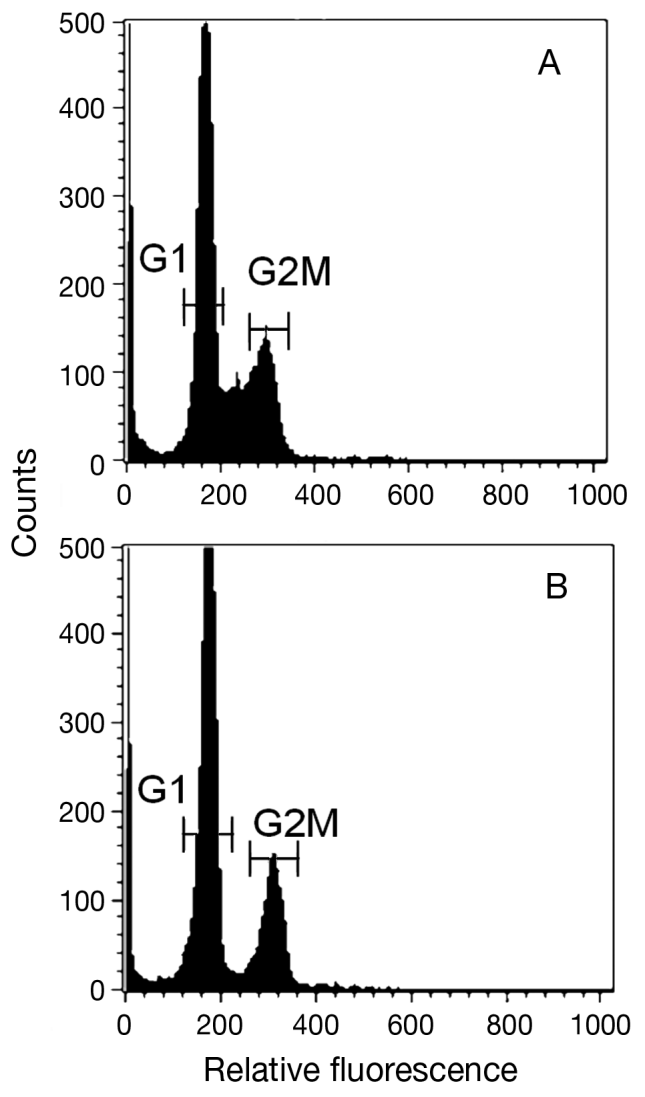

Fig. 6. Dinophysis acuminata. Examples of histograms of green fluorescence intensity (collected as pulse area) from the flow cytometric analysis on SYTOX Green stained cells. Horizontal bars show the fluorescence range assigned to each subpopulation of cells (G1, G2M). These ranges were used for the physical separation of cells in the flow cytometer. (A) Cells from Day 1. (B) Cells from Day 6

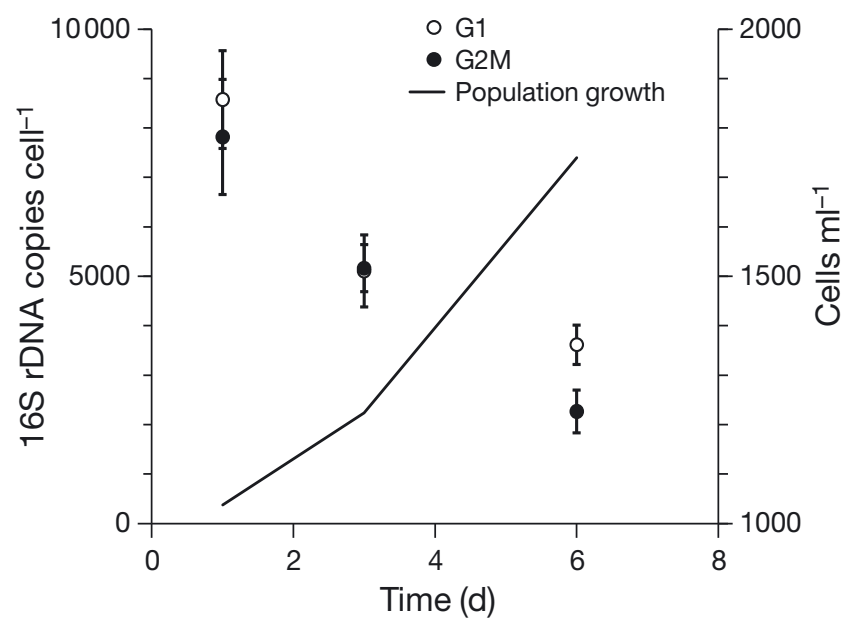

Fig. 7. 16S rDNA copies cell ${ }^{-1}$ analysed in single (G1) cells and mitotic plus paired $(\mathrm{G} 2 \mathrm{M})$ cells (mean $\pm \mathrm{SD}, \mathrm{n}=2$ cultures) through division at Day 6 the replication of nuclear DNA was not matched by a concomitant continuous replication of plastid DNA.

\section{Comparison with related studies}

Quantitative real-time PCR has been used before to search for patterns of DNA replication, in a number of studies including that of Myrionecta rubra by Johnson et al. (2006). Those investigators found that M. rubra could in fact keep a stable level of plastid DNA per cell while dividing in culture without its cryptophyte prey, although not for a long term, which is different from the results of the present study on Dynophisis caudata. When deprived of food M. rubra also increased their photosynthetic performance (Johnson \& Stoecker 2005). In conclusion, M. rubra must have acquired a plastid DNA replication ability. As it seems unlikely that a ciliate would have permanent secondary plastids, the nature of this special host-plastid relationship has been debated (Hansen \& Fenchel 2006, Johnson et al. 2007). Future studies about the M. rubra plastid are of great relevance also for the understanding of the Dinophysis plastid.

The coupling between feeding and photosynthetic activity in Dinophyis acuminata was measured by Riisgaard \& Hansen (2009) using a feeding/starvation strategy similar to the one described here. When depleted of prey, photosynthetic activity in $D$. acuminata decreased 6 -fold during a period of 4 to $6 \mathrm{~d}$, and eventually stabilised at a level of $6.6 \mathrm{pg} \mathrm{C}$ cell $^{-1} \mathrm{~h}^{-1}$, at the time when the cells stopped growing. Also, when ciliate prey was added in the beginning of their study, photosynthetic rates of $D$. acuminata increased from about 7 to $38 \mathrm{pg} \mathrm{C}$ cell $^{-1}$ within $2 \mathrm{~d}$ (Riisgaard \& Hansen 2009). The increase in photosynthetic activity during $2 \mathrm{~d}$ of feeding conditions measured by Riisgaard \& Hansen (2009) is comparable with the 7 -fold increase in plastid DNA per cell measured after $8 \mathrm{~d}$ of feeding conditions in the present study. On the whole, the similarity in time and magnitude of the decreases and increases measured in these 2 different studies suggests that the variability in photosynthetic rates in $D$. acuminata measured by Riisgaard \& Hansen (2009) could be a direct consequence of the changes in plastid DNA per cell as measured in the present study. Both studies also suggest that there is some critical threshold for the photosynthesis or amount of plastids, below which the cells can no longer divide without food supply.

Taken together, the total evidence presently available leaves little doubt that Dinophysis spp. have an ongoing uptake of plastids from Myrionecta rubra, even though the morphological differences between Dinophysis spp. and M. rubra observed by Garcia- 
Cuetos et al. (2010) remains to be explained. One cannot discard the possibility that kleptoplastids from the environment are picked up and that, at the same time, a permanent plastid of the Teleaulax type is resident within Dinophysis (Park et al. 2010). The present knowledge on Dinophysis plastids, such as the observed morphological differences between different plastids (Nagai et al. 2008, Garcia-Cuetos et al. 2010) and the fact that in cases where some novel cryptophyte plastid has been found inside Dinophysis, the 'original' Dinophysis plastid (i.e. the T. amphioxeia type) was also concurrently found (Minnhagen \& Janson 2006), might suggest that this is the case.

\section{CONCLUSIONS}

The present study verifies an active uptake of kleptoplastids or plastid components by Dinophysis caudata from its prey Myrionecta rubra. It also demonstrates that when starved, D. caudata had no significant replication of plastid DNA. Overall, the results from our present experiments show the pattern expected of a kleptoplastidic species, except the observation that living D. caudata never completely lost all their plastid DNA. Thus, we cannot exclude the possibility that some kind of semi-permanent plastid is resident in D. caudata, but nevertheless, this plastid-host relationship must still depend on an active feeding of M. rubra to support plastid division and photosynthesis. The implication is that not only the prey itself but also the availability of suitable kleptoplastids in the water might be an important controlling factor for Dinophysis spp. bloom formation and decline.

Acknowledgements. This work was supported by a National Research Foundation of Korea Grant funded by the Korean Government (2009-0066796) to M.G.P., the Infrastructuring Grant for Marine Biotechnology Program funded by Ministry of Land, Transportation and Marine Affairs to W.Y., and the Faculty of Natural Sciences, University of Kalmar, Sweden.

\section{LITERATURE CITED}

Adolf EJ, Stoecker DK, Harding LW (2006) The balance of autotrophy and heterotrophy during mixotrophic growth of Karlodinium micrum (Dinophyceae). J Plankton Res 28:737-751

Blackbourn D, Taylor F (1973) Foreign organelle retention by ciliates. J Protozool 20:286-288

Carvalho WF, Minnhagen S, Granéli E (2008) Dinophysis norvegica (Dinophyceae), more a predator than a producer? Harmful Algae 7:174-183

$>$ Douglas SE, Penny SL (1999) The plastid genome of the cryptophyte alga, Guillardia theta: complete sequence and conserved synteny groups confirm its common ancestry with red algae. J Mol Evol 48:236-244
Fields SD, Rhodes RG (1991) Ingestion and retention of Chroomonas spp. (Cryptophyceae) by Gymnodinium acidotum (Dinophyceae). J Phycol 27:525-529

> Garcia-Cuetos L, Moestrup O, Hansen PJ, Daugbjerg N (2010) The toxic dinoflagellate Dinophysis acuminata harbors permanent chloroplasts of cryptomonad origin, not kleptochloroplasts. Harmful Algae 9:25-38

Gisselson LÅ, Carlsson P, Granéli E, Pallon J (2002) Dinophysis blooms in the deep euphotic zone of the Baltic Sea: Do they grow in the dark? Harmful Algae 1:401-418

> Gustafson DE, Stoecker DK, Johnson MD, Van Heukelem WF, Sneider K (2000) Cryptophyte algae are robbed of their organelles by the marine ciliate Mesodinium rubrum. Nature 405:1049-1052

Hackett JD, Anderson DM, Erdner DL, Bhattacharya D (2004) Dinoflagellates: a remarkable evolutionary experiment. Am J Bot 91:1523-1534

> Hansen PJ, Fenchel T (2006) The bloom-forming ciliate Mesodinium rubrum harbours a single permanent endosymbiont. Mar Biol Res 2:169-177

Horiguchi T, Pienaar RN (1992) Amphidinium latum (Dinophyceae), a sand-dwelling dinoflagellate feeding on cryptomonads. Jpn J Phycol 40:353-363

Janson S (2004) Molecular evidence that plastids in the toxinproducing dinoflagellate genus Dinophysis originate from the free-living cryptophyte Teleaulax amphioxeia. Environ Microbiol 6:1102-1106

Janson S, Granéli E (2003) Genetic analysis of the psbA gene from single cells indicates a cryptomonad origin of the plastid in Dinophysis (Dinophyceae). Phycologia 42: $473-477$

Janson S, Gisselson LÅ, Salomon PS, Granéli E (2000) Evidence for multiple species within the endoparasitic dinoflagellate Amoebophrya ceratii as based on 18S rRNA gene-sequence analysis. Parasitol Res 86:929-933

Johnson MD, Stoecker DK (2005) Role of feeding in growth and photophysiology of Myrionecta rubra. Aquat Microb Ecol 39:303-312

$>$ Johnson MD, Tengs T, Oldach D, Stoecker DK (2006) Sequestration, performance, and functional control of cryptophyte plastids in the ciliate Myrionecta rubra (Ciliophora). J Phycol 42:1235-1246

> Johnson MD, Oldach D, Delwiche CF, Stoecker DK (2007) Retention of transcriptionally active cryptophyte nuclei by the ciliate Myrionecta rubra. Nature 445:426-428

Keeling PJ (2010) The endosymbiotic origin, diversification and fate of plastids. Phil Trans R Soc Lond B Biol Sci 365:729-748

Kim S, Kang YG, Kim HS, Yih W, Coats DW, Park MG (2008) Growth and grazing responses of the mixotrophic dinoflagellate Dinophysis acuminata as functions of light intensity and prey concentration. Aquat Microb Ecol 51: $301-310$

Larsen J (1988) An ultrastructural study of Amphidinium poecilochroum (Dinophyceae), a phagotrophic dinoflagellate feeding on small species of cryptophytes. Phycologia 27: 366-377

Lopez E (1979) Algal chloroplasts in the protoplasm of three species of benthic foraminifera: taxonomic affinity, viability and persistence. Mar Biol 53:201-211

Melkonian M (1996) Phylogeny of photosynthetic protists and their plastids. Verh Dtsch Zool Ges 89:79-96

> Minnhagen S, Janson S (2006) Genetic analyses of Dinophysis spp. support kleptoplastidy. FEMS Microbiol Ecol $57: 47-54$

> Minnhagen S, Carvalho WF, Salomon PS, Janson S (2008) Chloroplast DNA content in Dinophysis (Dinophyceae) 
from different cell cycle stages is consistent with kleptoplasty. Environ Microbiol 10:2411-2417

Nagai S, Nitshitani G, Tomaru Y, Sakiyama S, Kamiyama $\mathrm{T}$ (2008) Predation by the toxic dinoflagellate Dinophysis fortii on the ciliate Myrionecta rubra and observation of sequestration of ciliate chloroplasts. J Phycol 44: 909-922

Nishitani G, Nagai S, Sakiyama S, Kamiyama T (2008a) Successful cultivation of the toxic dinoflagellate Dinophysis caudata (Dinophyceae). Plankton Benthos Res 3:78-85

Nishitani G, Nagai S, Takano Y, Sakiyama S, Baba K, Kamiyama T (2008b) Growth characteristics and phylogenetic analysis of the marine dinoflagellate Dinophysis infundibulus (Dinophyceae). Aquat Microb Ecol 52: 209-221

> Nowack E, Melkonian M (2010) Endosymbiotic associations within protists. Phil Trans R Soc Lond B Biol Sci 365: 699-712

Park JS, Myung G, Kim HS, Cho BC, Yih W (2007) Growth responses of the marine photosynthetic ciliate Myrionecta rubra to different cryptomonad strains. Aquat Microb Ecol 48:83-90

Park MG, Kim S, Kim HS, Myung G, Kang YG, Yih W (2006) First successful culture of the marine dinoflagellate Dinophysis acuminata. Aquat Microb Ecol 45:101-106

Park MG, Park JS, Kim M, Yih W (2008) Plastid dynamics during survival of Dinophysis caudata without its ciliate prey. J Phycol 44:1154-1163

Park MG, Kim M, Kim S, Yih W (2010) Does Dinophysis caudata (Dinophyceae) have permanent plastids? J Phycol 46:236-242

Penna A, Bertozzini E, Battocchi C, Galluzzi L and others (2007) Monitoring of HAB species in the Mediterranean Sea through molecular methods. J Plankton Res 29:19-38

Pfaffl MW (2001) A new mathematical model for relative quantification in real-time RT-PCR. Nucleic Acids Res 29: 2002-2007

Editorial responsibility: Daniel Vaulot, Roscoff, France
Riisgaard K, Hansen PJ (2009) Role of food uptake for photosynthesis, growth and survival of the mixotrophic dinoflagellate Dinophysis acuminata. Mar Ecol Prog Ser 381: 51-62

- Rumpho ME, Worful JM, Lee J, Kannan K and others (2008) Horizontal gene transfer of the algal nuclear gene $p s b O$ to the photosynthetic sea slug Elysia chlorotica. Proc Natl Acad Sci USA 105:17867-17871

Schnepf E, Elbrachter M (1988) Cryptophycean-like double membrane-bound chloroplast in the dinoflagellate, Dinophysis Ehrenb.: evolutionary, phylogenetic and toxicological implications. Bot Acta 101:196-203

Schnepf E, Elbrachter M (1992) Nutritional strategies in dinoflagellates - a review with emphasis on cell biological aspects. Eur J Protistol 28:3-24

Skovgaard A (1998) Role of chloroplast retention in a marine dinoflagellate. Aquat Microb Ecol 15:293-301

Strepp R, Scholz S, Kruse S, Speth V, Reski R (1998) Plant nuclear gene knockout reveals a role in plastid division for the homolog of the bacterial cell division protein FtsZ, an ancestral tubulin. Proc Natl Acad Sci USA 95:4368-4373

Takahashi Y, Takishita K, Koike K, Maruyama T, Nakayama T, Kobiyama A, Ogata T (2005) Development of molecular probes for Dinophysis (Dinophyceae) plastid: a tool to predict blooming and explore plastid origin. Mar Biotechnol 7:95-103

Takishita K, Koike K, Maruyama T, Ogata T (2002) Molecular evidence for plastid robbery (kleptoplastidy) in Dinophysis, a dinoflagellate causing diarrhetic shellfish poisoning. Protist 153:293-302

Trench R (1975) Of 'leaves that crawl': functional chloroplasts in animal cells. Symp Soc Exp Biol 29:229-265

Wilcox LW, Wedemayer GJ (1984) Gymnodinium acidotum Nygaard (Pyrrophyta), a dinoflagellate with an endosymbiotic cryptomonad. J Phycol 20:236-242

Yih W, Kim HS, Jeong HA, Myung G, Kim YG (2004) Ingestion of cryptophyte cells by the marine photosynthetic ciliate Mesodinium rubrum. Aquat Microb Ecol 36:165-170

Submitted: March 31, 2010; Accepted: September 12, 2010 Proofs received from author(s): November 22, 2010 